\title{
The Oral Folk Literature of the Ancient Meiteis of Manipur: An Analysis of its Cultural Significance
}

Thounaojam Caesar $^{+*}$ and Reena Sanasam ${ }^{\check{1}}$

\section{Abstract}

Oral narratives are the earliest forms of storytelling as they exist in every culture as a part of religious rituals, folk music and songs. They include ritual texts, curative chants, epic poems, musical genres, folk tales, creation stories, songs, myths, spells, legends, proverbs, riddles, tongue twisters, word games, recitations and other narratives not recorded in writing. With the invention of writing, the ancient forms of oral narratives have undergone a lot of changes and have become valuable works of literature. However, the charm of oral narratives often told by improvisation and even gestures as a part of tradition cannot be transcribed into literature. As oral stories are brought down from generation to generation and are committed only to the memory, the various stages of the growth of such narratives give an account of the culture of the people. These are the sources of popular entertainment and are closely associated with festivals and religious ceremonies. At present, our society feels the need to safeguard and protect these indigenous forms of arts from the danger of extinction due to the impacts of globalisation and commercial entertainments. The exploration of the meanings and themes of ancient narratives, in a broader social context, and the significant role of the variant folklore genres in maintaining collective wisdom, national identity, solidarity and traditional moral values are points of great concern in this study.

Keywords: Oral Folk Literature, Ancient Meiteis, Cultural Significance, Manipur, India

\footnotetext{
${ }^{\dagger}$ Research Scholar, Department of Humanities \& Social Sciences, National Institute of Technology, Silchar, Assam, India, Email: tsarjam@gmail.com

${ }^{*}$ Corresponding Author

İReena Sanasam, Assistant Professor, Department of Humanities \& Social Sciences, National Institute of Technology, Silchar, Assam, India, Email: reena_sanasam@yahoo.com

C2018 Caesar and Sanasam. This is an Open Access article distributed under the terms of the Creative Commons Attribution License (http://creativecommons.org/licenses/by/2.0), which permits unrestricted use, distribution, and reproduction in any medium, provided the original work is properly cited.
} 


\section{Introduction}

Literature is concerned with the written language. But a world without writing and free of writers will be a very inhospitable place as we cannot even imagine a situation where we have nothing to read or write. A world of no newspapers, no magazines, no internet and no words, as the building blocks of human expression and no information is something beyond our imagination. If our means of communicating with each other is not there, we cannot live our life. However, there is a fascinating aspect of this assertion. It is a fact that people used to live for many thousands of years and established remarkable civilisations throughout the world without writing. As we all know writing came to the world much later during the period of ancient civilisations in Mesopotamia, Egypt, India and China. Many historians believe that this strange phenomenon of writing, developed in many parts of the world independently, constitutes a complex society, and this system is crucial to a society's evolution towards more complexity. Now it seems that we have reached the zenith of sophistication as we miss the jungle for the trees.

The influence of verbal language has not been adequately understood by those who give much emphasis to writing. Words would have been more meaningful when we communicate directly than in writing. So, spoken communication in literature will have to be taken much more seriously than the written form of communication through the ages of civilisation was done without writing. Among the vast gamut of literary narratives communicated through generations, our writers have started to collect only a microscopic fraction as written literature. A significant portion of such narratives is found in oral tradition, commonly known as oral literature.

As oral stories are brought down from generation to generation and are committed only to memory, the various stages of the growth of such narratives give an account of the culture of the people. They also operate in many ways as literature. The term 'orature' is sometimes used to denote something passed on through the spoken word, and because it is based on the spoken word, it comes to life only in a living community. Where community life fades away, orality loses its function and dies. It needs people in a living social setting, unlike written literature which may exist without society. But what is most important here is to try to distinguish the process by which each literary art comes into being, its specific function in a given space and time, and the context within which it is told or written. Besides formal elements, the former involves national pride, ethical issues and identities; whereas the latter focuses mainly on formal aspects such as characters, devices, plots, artistic merit and others. Ch. Manihar Singh (2003: 12) asserts that:

Ritual songs and hymns may be said to have ushered in the dawn of early Manipuri poetry or, for that matter, Manipuri literature. They are not folk songs which should have been, as commonly believed, on the lips of every man and woman in a society and handed down to the following generations. In the case of these sacred songs not only were they meant for particular ceremonial functions, ritual observances and festive occasions, but they also required a Corps de' elite of performers to render them. No doubt, some of them are devoid of literary merit, but the rest definitely set the pace.

This paper summarises the significance of Meitei oral traditions in transmitting Meitei traditional values and preserving Meitei unique culture and traditions.

\section{Materials and Methodology}

In order to widen the purpose, our aim is to apply 'Cultural Studies' that serves as an apparatus to analyse cultural texts and social practices to reconstruct the experiences, values, norm, etc.; which Williams refers to be called as "structure of feeling" (a shared set of ways of thinking and feeling) of particular 
groups or whole societies, for a better understanding of lives of those who lived the culture (Turner 2003: 47). Williams asserts that "there is a recorded culture of every kind, from art to the most everyday facts" where its significance lies when such documentary culture clearly "expresses that life to us in a direct term when the living witnesses are silent"(1961: 19). Materials are collected by studying Meitei culture in various ways, by clustering texts, events, persons, objects, and ideologies into a cultural whole and bringing a mixture of coherent argument, speculative propositions, and empirical data, and political outlooks, creating a new kind of investigation immune to the methodological punch.

\section{Discussion of Literature}

Ancient Meitei lores have played an instrumental role in reinforcing national integrity, crystallising social solidarity, fortifying communal harmony, intensifying value system and promoting the elements of humanism among the natives. Since olden days of Meitei society, storytelling is one of the primary sources of re-creation. Phunga (hearth inside the house) is closely interwoven with the Meitei cultural practice of storytelling. While waiting for the food to be cooked by mother the other members of the family, grandparents and children sat around the hearth and grandparents tell stories, folk tales, fables and riddles to the children to awaken them before eating. Since the story is told near the hearth, it is called Phunga Wari ${ }^{1}$ and again it is told while waiting for the evening meal it is also known as the Chak Ngai wari. ${ }^{2}$ At the end of each story, the children try to relate the events to their natural social environment, discuss the theme of the stories, describe the characters, raise many questions and parents offer them explanations. In this way, the society has succeeded in handling on to its children the collective wisdom for centuries.

Besides cultural practice of storytelling, the hearth locally known as Phunga in Meitei

\footnotetext{
${ }^{1}$ Story told near the hearth commonly known as the folktale.

${ }^{2}$ Stories told while waiting for the meal.
}

language is closely interwoven with the Meitei a sacred place essential to venerate fire. Fire worship is practised depending on the construction of fire myths and legends of a particular culture. Unlike the Greeks Hestia, Vesta of the Romans and the Grihagni of the Hindus, the ancient Meitei style of worshipping fire is of different origin. Fire is made by various methods like striking flint and steel called meiyei, meiba, chakmom, khambi produced by rubbing a bamboo strip on dry wood are used for sacred rituals (Higgins 1997: 18).

The deity reciting the fireplace of every Meitei household is a goddess name Emoinu Ahongbi, the goddess of material needs and prosperity which acts as a counterpart of the Hindu Goddess Lakshmi. This fire is supposed to be maintained day and night. People pray to Goddess Emoinu residing in the fireplace of every Meitei household, to stay in the house forever. The goddess is venerated every year on the $12^{\text {th }}$ day of the month of Wakching (January). Every home is lit up to welcome Emoinu Ahongbi. The religious rituals for the worship of goddess Emoinu Ahongbi include the offering of Whitefish, fruits, flowers, vegetables, one meant for Lainingthou and other for Phunga Lairu. These are the translation of the opening lines of prayers to the goddess:

0 mother of cherish and nurture Manifestation of supreme Goddess Leimarel Never to be empty $\mathrm{O}$ mother Emoinu, the goddess of wealth and prosperity.... . (Budhichandra 1981: 29)

In a simple sense, the fire in the kitchen symbolises the abundance of food, for the reason that if there is no fire in the house we take it as the scarcity of food to cook implies to poverty. Thus making the conviction in a religious means by saying that 'fire in the kitchen must be kept ablaze day and night', our ancestors have devised the community through divine intervention to work hard to earn bread and milk. It is more secular than religious in its thematic structure; it has similarities with the wisdom literature of the Bible or the Bhagavata Gita in a sense that the instructive appeals of 
the wise saying not only serves as moral guideline rather every statement of the Meitei anecdote reveals the deeper problems of value of life, of good and evil and it represents a collection of moral ideas and principles based on experience and universal application.

From the earliest historical times, the civilisation of Manipur is based on agriculture, in which man's primary interests are concerned with birth and death, procreation and fertility, and the cycle of seasons. In the Meitei belief system, there is a goddess of harvest called Phouoibi, ${ }^{3}$ whose blessings are necessary for a bountiful crop. One of the fragments of the poem Phoukou Eshei (calling of the paddy) is as follows:

O Goddess, Phouoibi;

Please come to us

Produce heaps of Thangyi (a kind of paddy) for us

Please come to us

Profuse us what is fine and riches

Please come to us

Praise us with mount of Thangyi

Please come to us

O Goddess Phouoibi

Please come to us

In Meitei culture after harvesting, the threshing work is done on a mat made of bamboo called Louyei Phak in the field and the paddy thus collected heaping up in the form of a small mound after winnowing it out and is usually followed by worship and prayer to Goddess with hymn known as Phoukou Eshei (Phou means paddy; kou means to call up, and eshei means song) symbolising the welcoming of the collected harvest. The literal meaning of the word may be translated as the lore of calling the paddy. The lines of the poem depict the fertility cult and are still on trend in the Meitei society with some variations. The idea behind the lines is to call on Phouoibi (the goddess of paddy) and to venerate her for good harvest and prosperous production (Ayyappa 1997: 334). It is composed because of the human faculty of spiritual experience and intellectual

\footnotetext{
3 Phou means unhusked paddy and oibi means to turn into with a suffix $i$ denoting feminine gender.
}

development, and also the number of Gods and Goddesses representing the diverse elemental forces and qualities emerged (Ellwood 1927:113).

Manipuri culture has also got its diverse and distinct varieties of folk songs popularly known as Louta Eshei (songs of the tending harvest) sung during the work process.

It is the field of our father let us till it!

It is the field of our grandfather, let us till it!

It is the field which will bring peace to the land let us till it!

It is the field which will bring long life to the king, let us till it!

It is the field which will make the village and the land prosper, let us till it! (Parratt 1997: 142)

The poem reflects a sense of inheritance. It is a structure which is evolved in the course of a long process and a long history in the life of the people. With the passage of time, these practices had been refined and crystallised as a sacred tradition, in such a way, that it has become an integral part of Meitei culture.

Some of the early poems are composed to appreciate the qualities of flowers and its cultural implication. One of the lyrics, addressing the flower Ingellei (a flower that blooms in July) is as follows:

$\mathrm{O}$ Ingellei blooming in the mountain,

You are falling off without having been of any use.

It is a pity.

I am not falling on my own free will.

I am falling because of the current of air.

I (wind), too, am doing nothing

Because of the weakness of its stalk

The flower is falling, (Khelchandra1969: 46-47)

The poem Ingellei is a melancholy based on despair regarding the human circumstance. In 
its context, Ingellei is a metaphor for common folk whose stories are never reported in the story or recorded in history. The poem Ingellei reminds us of Gray's Elegy lines 55-56 when he writes:

Full many a flower is born to blush unseen,

And waste its sweetness on the desert air.

Like the beautiful flower which blooms and withers away before they can be seen for their beauty in the deep woods, their toil or role may not be seen or known, although it is nevertheless worthy. The flower, in reply, says that she is gradually withering not willingly but compelled by almighty time. According to R.K. Jhaljit Singh (1976:178), Ingellei refers to a beautiful woman of the high social strata. There are many such women inside the royal harem of Manipur, though their beauty attracts many people of the lower status likes them but are beyond their reach. Thus they are comparing to Ingellei flower that bloomed in the mountain high, and as desire remained unfulfilled, they were compared to flowers falling off without having been of any use.

Another group of scholars believe that Ingellei alludes to a historical event in the annals of the history of Manipur where King Charairongba (17 $7^{\text {th }}$ century) having an illicit affair with Nungthilchaiba, the daughter of a maidservant as a result of which she became pregnant. Charairongba could not keep her and her son in the palace due to the fear of objections from his courtiers. Nungthilchaiba died before he met her again. Thus, he lamented over such separation. Therefore, the flower Ingellei was compared to Nungthil Chaibi who sacrifices her youthful love for Charairongba.

The reverence of nature can be seen in the ancient poem HijanHirao literally meaning (the cry of the tree for making boat). Hijan Hirao gives details of the origin of boat making in Manipur. The legend of the discovery of boat is associated with Luwang King Punsiba who came to look for the tree at Shingtha Khandomyi and to see the reeds whether they are flowering red and white. There in the turbulent water, he saw a mouse carrying thatch in his mouth and cross the river floating in that way. Again, he saw a cricket with a grass in its mouth floating over the river. Punsiba then pushed a bamboo then it drifts. Then he put a stone on it but finds it still afloat. Then Punsiba got an idea of making a boat by cutting a huge tree. When he came back home, he advised two of his craftsman Wangmitkhu and Wangmanao to cut down a big tree and carved a huge boat (Hiyang Hiren) out of it. To make the boat looked attractive and decorative Sangai head (brow antler deer) was etched with wood and fixed to the prow of the boat. So, the construction of boat was started during the reign of Luwang King Punsiba (400-600 A.D.) on which the incident of the poem is based on. Hijan Hirao also reflects the lamentation of the Mother Nature.

O my son, tall and big,

While yet an infant, a sapling

Didn't I tell you?

To be an ordinary tree?

The King's men have found you out

And bought your life with gold and silver (Manihar 2003: 17).

Tomorrow at dawn the axe will fall upon you,

They will cut off your head, your crown,

On this beautiful mountainside

Called the Mountain of Sound,

Where they have feasted their eyes upon you. (Parratt 1997: 158)

The above lines are written in the form of an elegy depicting the act of cutting down the tree. Here the poet utters, we are cutting the tree as it is destined to cut down. Besides its beautiful narrative, the lamentation of Mother Nature goddess Irok Lai Chanu (Higgins 1997: 19) the day before the cutting of the tree ( $U$ Ningthou) shows the ancient Meitei sense of love and care for the nature and preservation and needs of the natural environment in 
human life. Rituals like the liberation of white buffalo now replaced by male Mithun, a white male goat, and a red hen are performed before cutting down the tree (Higgins 1997: 19). In the Laiharaoba festival, "the rejoicing of the gods" (Hodson 1908: 104), the presiding deity has to ascend to the heaven. It is rendered by the maibi $^{4}$ and the Hiroi (boat man) as:

$\mathrm{O}$ boat, $\mathrm{O}$ boat

We are not rowing you

But the Supreme deity,

We are rowing for the prosperity of the village, the country,

For peace in the land, we are rowing,

For the long life of the king, we are rowing,

For the abundance of the rice crop, for fish, we are rowing.

Having eaten of the early rice harvest,

For the reason, the community offers a boat for the deity to ride on it. And the boat here is used symbolically as a medium of spiritual transportation, generally believed to bring abundance, prosperity, happiness and welfare of the people. Here the poet says we are cutting the tree as it is destined to be cut down. The bard further asserts that the cutting of the tree is for the purpose of the service of the Lord. So, we must not feel bad and lament instead we must get rejoice. These poems formed a cluster of early Manipuri literature, which did not exist in writing.

${ }^{4}$ Kipgen says that the maibi being a priestess performs religious rites and mystics preoccupied with the acts of exorcism and healing or cursing.
Diverting from religious poems, Manipuri Khulang Eshei, (song at the time of lending hand in agriculture work) is a kind of poetry in which young men and maiden are given a chance to express their romantic feeling for each other in an orthodox manner and innovative way through songs. These are the songs mainly sung in the fields, lakes, and workplaces without a musical instrument. The young lad starts singing by addressing a group of girls working nearby. One of the girls from the group gives a confusing reply to the question of a young man by singing. In the culture of Manipur, man is compared to the bee and girl is compared to a beautiful flower.

Oh, my darling, lotus-like lady,

Do you hear me,

On seeing your face

Which is as beautiful as the tree lotus

Growing in the land of hill. (Kirti 1993: 49)

Another adaptation of the poem is as follows:

Young man: Sweet flower, maiden, most beautiful one

O flower at your first glance

I am speechless

As if fish-bone stuck in my throat

Enchantress of my heart

And for me the mountain bee

On which day may I propose

By saying the magical words

Anticipated to convey you as darling.

Maiden: O my admirable bee;

When I hear your youthful voice

My maiden's heart loses.

The strength of the tiger

Is the thick forest,

The strength of the bird,

Is the current of air

The strength of the female 
Is the man,

The strength of the man

Is the female,

Express your desire to me.

Tell me your wish.

As time is out of hand, my dear.

The feelings espoused in such songs are the products of the singer's own experience, and the composition is exclusively his piece of a song composed on the spot according to the situation, and it serves as the cultural and literary position for the countrified that composes it. It is one of the most striking examples of romantic comedy and emotional love poetry in rural Manipuri, especially among the young population. The poem includes an idealised view of the relation between the narrator and that of the anonymous personality, a lady, and how the existing imagery, essence and ideas are artistically exposed and located correctly in verse. The philosophy behind such lyrics to the cultural practice of Manipur is straightforward in a sense as the rhythm of the song serves to synchronise physical movement in groups, coordinating sowing, hoeing and harvesting. While exchanging amorous conversations, they repel the tiredness of the body and reduce dullness. The technique of employing a variety of panegyric words shows submission, an intention to compromise and creates love in a civilised manner. He treats the beauty of a woman and imagery is drawn not only from an exotic woman but also sexual desires and her charming body and personality in a melodious voice by romantically describing her physical stature. Both pure and figurative languages are used, and in most cases, the narrators employ local fabric.

Many of the oral narratives and legends along with rituals are store in Meitei tradition regarding the rain. There exists a peculiar tradition of Rainmaking and Rain stopping ceremonies adopt by the ancient Meiteis if there is no seasonal rainfall causing drought or heavy rain causing the flood. Whenever rain is scarce, the priest and experts perform rain calling rites at NongjuKhong (Langjing hill). One of the most accepted folk songs of calling out Soraren (rain god) is known as the Nonglao Eshei given below:

\section{O rain, pour down}

Sink the peak of Langjing

Float along maidens of Patsoi

Let the youth of Unam pick them up (MS Chinglon Laihui)

Experts perform the actual Nonglao Eshei in a ritualistic manner. Frazer (2012: 304-305) writes, "In Manipur, on a lofty hill to the east of the capital, there is a stone which the popular imagination likens to an umbrella. When rain is wanted, the rajah fetches water from a spring below and sprinkles it on the stone." So, ritual expresses the community's hopes and fears. It brings them together in an environment that permits such feelings to be openly expressed and shared. Thus, the ancient artistic creation is said to inspire from human experiences.

In its gradual process of formation, much of ancient Manipuri poetry is lost and the few extant that claim to have been composed before the arrival of Hindu culture often shows marks of subsequent modifications and interpolations. In the rain stopping the ritual practice of the Meitei culture the manuscript containing the rituals of rain stopping is kept on a stand made on top of the fireplace. The rain stopper stirred the sand with a spoon chanting the charm Ong Karo Ong karo. It is believed that when the book and the sand are warm, Sorarel (sky god) will warm the earth and the air. If this ritual also doesn't work, the words Ong Karo Ong karo is written on a billet of wood and weaved it around his head until the cloud breaks. While weaving, he pronounces the word,

Guru thang dichumthangni, Gurugichunggoi di leichinne, leichinnong phaikaibane, Setkaiusettumu, Mapugi thang di tongonba, haikup, haiphra. Thabat, thabathiragi di thangne haidatlo. 
OngDurga Debi kapacheyo! Ong Jadurakha Debi, kapacheyo. Swarha Ong Debi, kapacheyo, Swarha! Durgagi thang ne SegaksegakKhaio! Khaio! Tumo (Shakespear1911: 349-350).

Looking at the mixture of Devanagari words like guru, ong, debi, Durga in archaic Meitei, M. Kirti Singh writes:

The Meiteis used incantations, hymns, etc. very frequently along with those of Hindu and Buddhist origin and thus also set a Living example of synthesis in this place wherein Tantricism was thought to lie in words and phrases of Mystic significance of the Vedic syllable Om and Tantric symbol Hum occur in the available treatises (Kirti 2007: 19).

The compositions of ballads using different languages are found abundant reflecting the assimilation of different cultures. Robinson asserts that:

In Manipur, Hinduism was adopted by the state and with it came the hegemony of the Bangla language. Many rare Meitei puranas and manuscripts were destroyed because they were once perceived as a hindrance to the spread through modes of singing and devotional meetings. ......for instance, it was as late as in the second quarter of the eighteenth century that through the efforts of the King's preceptor, a Bengali Brahmin and follower of Ramananda named Santidas, attempts were made to organize Meitei society on caste lines by giving recognition to the Meiteis themselves as Kshatriyas and instating the immigrant Bengali Brahmins as the Brahmins of Meitei society (Robinson 2004: 33).

Such a unique mixture of Sanskrit words with the Manipuri invocation, and the impartial appeal to the gods of the Hindu pantheon and the local divinities, precisely shows the religion of the present Manipur. Shakespeare says "is typical of the religious muddle in which the people are" (Shakespear1911: 249). Hodson also gives a personal observation about the religion of the land. He says: "The Meiteis are now in a stage, through which many now most orthodox Hindu clans must have passed. But it may safely be prophesied that the resultant faith will bear clear marks of the Meitheis ancient animism" (Hodson1908: 188). Even though some narratives discuss above survived because of its values and practised by the people even today. This made the old religion, culture, heritage and customs more luminous because literature and the practices of Hinduism could not infiltrate the ancient scriptures and some corner of the traditional practices of Manipur (Meiteis).

\section{Conclusion}

Therefore, the process of creativity and literary development within the context of innate modernity mean, we view ourselves in the contemporary world regarding our social environment, and preserve those values and norms which are culturally and socially relevant to us. Ancient Meitei literature thus illustrates a value using which they declare themselves as part of the cultural history of the land. They can reveal the people's cultural practices, feelings and wishes in a sincere, direct manner by expressing the cultural elements, temperament, force, wit and wisdom, as well as the sense of humour that a nation exhibits. The most important is the collective conscience they produce. The integrity of individuals and equipping them to meet social challenges are an integral part. Majority of the literature is generally associated with agriculture, procreation, and religious rituals and the ancient gods and goddesses associated with them. It also carries thousands of years old cultural motifs to the future and assumes a vital role in preserving cultural heritage. A good number of literature developed during ancient period reflect superstitious beliefs that in making ritual sacrifices to the gods in appreciation of the harvest, one could persuade the gods to provide another bountiful harvest in the following year. Thus it reflects the peculiarity of Meitei community's religious, 
cultural and historical narrative, as it has the unique philosophy, aesthetic appeal and their colloquial languages which naturally reflect their unique narrative. Some of the literature are inspired by local myths and legends originating from their culture and closely reflecting their way of life and promoting the elements of humanism among the people of the realm.

\section{References}

Anonymous.ChinglonLaihui (MS).

Budhichandra, Y and N. Manishana (1981). Emoinu Ahongbigi Tungnaphum. Collected works of Goddess Emoinu. Imphal: Meetei Lichat Sajat Semgatpa Kanglup (Manishana), p. 29

Charles Ellwood, A. (1927). "Primitive Concepts and the Origin of Cultural Patterns", American Journal of Sociology, Vol. 33, No. 1, pp. 1-13. <http://www.jstor.org/stable/2765036>

Frazer, James G. (2012). The Golden Bough: A Study in Magic and religion. Vol. 1. $3^{\text {rd }}$ Ed. New York: Cambridge University Press, p.304-305

Gray, Thomas. (1751). An Elegy written in a Country Churchyard. $5^{\text {th }}$ Ed. London: R. Dodsley in Pall Mall. p. 8

Higgins, J.C. (1997). Notes on Meithei (Manipuri) Beliefs and Customs. Imphal: Manipur State Archive, p. 18-19

Hodson, T. C. (1908). Reviews. MAN: A Monthly Record of Anthropological Science. London: Royal Asiatic Society, p. 188

Hodson, T. C. (1908). The Meitheis. London: David Nutt, Long Acre,. Rpt.2007. p. 104 (ISBN, 978-0-282-10301-9)

Jhaljit, R.K. (1976). A History of Manipuri Literature. Imphal: O.K. Store, p.178

Khelchandra, N. (1969). Ariba Manipuri Sahityagi Itihas. Imphal, p. 46-47

Kipgen, T.G. (2010). Women's Role in the $20^{\text {th }}$ century Manipur: A Historical Study. Delhi: Kalpaz Publications, p. 44.
Kirti, M (1993). Folk Culture of Manipur. Delhi: Manas Publication, p. 49, 128 (ISBN: 81-7049063-4)

Kirti, M (2007). Philosophy and Religion. New Delhi: Akansha Publishing House, p. 19

Manihar, Ch. (2003). A History of Manipuri Literature, $2^{\text {nd }} E d$. New Delhi: Sahitya Akademi, p. 12-17 (ISBN: 8126015861, 9788126015863)

Paniker, K. Ayyappa. (1997). Medieval Indian Literature: An Anthology. Vol. 1. New Delhi: SahityaAkademi, p.334

Parratt, S.N. (1997). The Pleasing of the Gods: Meitei Lai haraoba. New Delhi: Vikas Publishing House Ltd., p. 142-158 (ISBN: 0-631-20359-1)

Robinson, R. (2004). "Introduction." Sociology of Religion in India. New-Delhi: Sage Publications Inc., p. 33

Shakespear, J. (1911). "A Note on the RainStopping in Manipur". Folklore Journal. Vol. 22. London: David Nutt, Long Acre, p. 249-350

Turner, G. (2003). British Cultural Studies: An Introduction. $3^{\text {rd }}$ ed. London: Routledge. $p$. 47(ISBN 0-415-25227-X)

Williams, R. (1961). The Long Revolution. London: Penguin Books Ltd, p. 19 (ISBN: 155111-402-X)

\section{Acknowledgements}

Authors are thankful to the Department of Humanities and Social Sciences, National Institute of Technology, Silchar for providing the Scholarship. We are also indebted to Professor Th. Ratankumar Singh of Department of English, and Director, College Development Council, Manipur University for his immeasurable support and valuable comments.

We also thank our anonymous reviewers for their careful reading of our manuscript and their many insightful comments and suggestions. The revisions carried out in this paper reflect their suggestions and comments towards strengthening its research arguments and overall theoretical basis. 